\title{
Depoliticizing Administrative Law
}

\section{Citation}

Cass R. Sunstein \& Thomas J. Miles, Depoliticizing Administrative Law (John M. Olin Program in Law \& Economics Working Paper No. 413, 2008).

\section{Published Version}

http://chicagounbound.uchicago.edu/law_and_economics/167/

\section{Permanent link}

http://nrs.harvard.edu/urn-3:HUL.InstRepos:12795541

\section{Terms of Use}

This article was downloaded from Harvard University's DASH repository, and is made available under the terms and conditions applicable to Open Access Policy Articles, as set forth at http:// nrs.harvard.edu/urn-3:HUL.InstRepos:dash.current.terms-of-use\#OAP

\section{Share Your Story}

The Harvard community has made this article openly available.

Please share how this access benefits you. Submit a story.

\section{Accessibility}




\section{University of Chicago Law School Chicago Unbound}

Coase-Sandor Working Paper Series in Law and

Economics

Coase-Sandor Institute for Law and Economics

2008

\section{Depoliticizing Administrative Law}

Cass R. Sunstein

Thomas J. Miles

Follow this and additional works at: http://chicagounbound.uchicago.edu/law_and_economics

Part of the Law Commons

\section{Recommended Citation}

Cass R. Sunstein \& Thomas J. Miles, "Depoliticizing Administrative Law" (John M. Olin Program in Law and Economics Working Paper No. 413, 2008).

This Working Paper is brought to you for free and open access by the Coase-Sandor Institute for Law and Economics at Chicago Unbound. It has been accepted for inclusion in Coase-Sandor Working Paper Series in Law and Economics by an authorized administrator of Chicago Unbound. For more information, please contact unbound@law.uchicago.edu. 


\section{CHICAGO}

John M. Olin LaW \& EConomics Working PAPER No. 413

(2D SERIES)

Public LaW and Legal Theory Working Paper No. 223

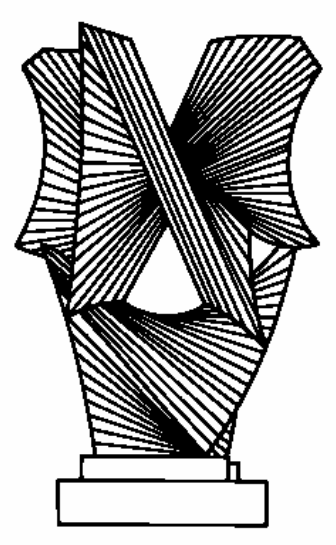

DEPOLITICIZING ADMINISTRATIVE LAW

Thomas J. Miles and Cass R. Sunstein

\section{THE LAW SCHOOL THE UNIVERSITY OF CHICAGO}

June 2008

This paper can be downloaded without charge at the John M. Olin Program in Law and Economics Working Paper Series: http://www.law.uchicago.edu/Lawecon/index.html and at the Public Law and Legal Theory Working Paper Series: http://www.law.uchicago.edu/academics/publiclaw/index.html and The Social Science Research Network Electronic Paper Collection: http://ssrn.com/abstract $=1151984$ 


\title{
Depoliticizing Administrative Law
}

\author{
Thomas J. Miles* and Cass R. Sunstein ${ }^{* *}$
}

\begin{abstract}
A large body of empirical evidence demonstrates that judicial review of agency action is highly politicized, in the sense that Republican appointees are significantly more likely to invalidate liberal agency decisions than conservative ones, while Democratic appointees are significantly more likely to invalidate conservative agency decisions than liberal ones. These results hold for both (a) judicial review of agency interpretations of law and (b) judicial review of agency decisions for "arbitrariness" on questions of policy and fact. On the federal courts of appeals, the most highly politicized voting patterns are found on unified panels, that is, on panels consisting solely of either Democratic or Republican appointees. On the Supreme Court, politicized administrative law is also unmistakable, as the more conservative justices show a distinctive willingness to vote to invalidate liberal agency decisions, and the more liberal justices show a distinctive willingness to vote to invalidate conservative agency decisions. Indeed, it is possible to "rank" justices in terms of the extent to which their voting patterns are politicized. The empirical results raise an obvious question: What might be done to depoliticize administrative law? Three sets of imaginable solutions have promise: (1) self-correction without formal doctrinal change, produced by a form of "debiasing" that might follow from a clearer judicial understanding of the current situation; (2) doctrinal innovations, as, for example, through rethinking existing deference principles and giving agencies more room to maneuver; and (3) institutional change, through novel voting rules and requirements of mixed panels. An investigation of these solutions has implications for other domains in which judges are divided along political lines, and indeed in which nonjudicial officials show some kind of politicized division or bias.
\end{abstract}

\section{Introduction}

Imagine a parallel world, very much like our own. In this world, administrative law is radically politicized. If the question is the legality of an agency's interpretation of a statutory term, the court's answer can be predicted by asking about the political affiliation of the president who appointed the judges on the panel. If the question is whether an agency's decision is arbitrary or capricious, the court's answer can be predicted in the same way. In such a world, the crudest versions of legal realism would be vindicated: Whatever the formal doctrine, the outcome of disputes in administrative law would be a product of the judges' political predilections. Administrative law would be a matter of judicial politics.

\footnotetext{
${ }^{*}$ Assistant Professor of Law, University of Chicago Law School

${ }^{* *}$ Felix Frankfurter Professor of Law, Harvard Law School.
} 
Fortunately, that world is not our own. Disputes about the legality of agency action cannot be predicted in so simple a fashion. ${ }^{1}$ Unfortunately, however, that world has something in common with our own. ${ }^{2}$ In the last three administrations-under Presidents George H.W. Bush, Bill Clinton, and George W. Bush-administrative law has been highly politicized, in the sense that on the courts of appeals, the evidence reveals sharp divisions between Republican and Democratic appointees, in a way that fits uncomfortably well with ideological stereotypes. ${ }^{3}$ On the Supreme Court, the situation is even worse. Some members of the Court—above all Justices Clarence Thomas and John Paul Stevens - show highly ideological voting patterns, in the sense that their willingness to vote to validate an agency's interpretation of law can be predicted, much of the time, by asking whether the interpretation is conservative or liberal. ${ }^{4}$

To say the least, this is a disturbing and somewhat embarrassing state of affairs. Whatever one's view of the foundational questions in administrative law, no one should approve of a situation in which judicial voting patterns are highly politicized. ${ }^{5}$ On the contrary, it is reasonable to read existing doctrines as an explicit effort to prevent such patterns from emerging. Consider Chevron v. NRDC, ${ }^{6}$ which establishes that courts must uphold agency interpretations of ambiguous statutory provisions so long as those interpretations are reasonable. ${ }^{7}$ Chevron is naturally read to say that resolution of statutory ambiguities calls for a policy judgment, ${ }^{8}$ with the suggestion that such

\footnotetext{
${ }^{1}$ See Thomas Miles and Cass R. Sunstein, Do Federal Judges Make Regulatory Policy, 73 U Chi L Rev 823 (2006); Thomas Miles and Cass R. Sunstein, The Real World of Arbitrariness Review, U Chi L Rev. (forthcoming 2008). In those essays, we elaborated a long series of empirical findings without much discussing the normative implications, and without focusing on how politicized voting patterns might be reduced. We attempt to fill those gaps here.

${ }^{2}$ For a seminal study, see Richard Revesz, Environmental Regulation, Ideology, and DC Circuit, 83 Virginia L Rev. 1717 (1983).

${ }^{3}$ See id; Miles and Sunstein, Federal Judges, supra note; Miles and Sunstein, Real World, supra note. These essays, focused on administrative law, should be seen as part of a large and growing area of empirical study. For discussion and citations, see Thomas Miles and Cass R. Sunstein, The New Legal Realism, U Chi L Rev (forthcoming 2008).

${ }^{4}$ See Miles and Sunstein, supra note.

${ }^{5}$ If agency decisions have an ideological skew, of course, it might be desirable to have a high level of invalidations; and if the agency's skew leads to a high level of unlawful "liberal" decisions, then a percentage of invalidation of such decisions would be nothing to deplore. The problem is that even if agency decisions are skewed in one or another direction, a large and predictable split between Republican and Democratic appointees would be hard to defend, and would justify a high level of concern.

${ }^{6} 467$ US 837 (1984).

${ }^{7}$ Id. at 843-44.

${ }^{8}$ See E. Donald Elliott, Chevron Matters, 16 Villanova Env LJ 1 (2005).
} 
judgments should be made by administrators, not judges. ${ }^{9}$ It is disconcerting, to say the least, to find that when judges review agency interpretations of law, judicial policy judgments are playing a significant role.

Or consider Motor Vehicles Manu. Assn. v. State Farm, ${ }^{10}$ which specifies how judges are to evaluate agency decisions challenged as arbitrary or capricious under the Administrative Procedure Act. ${ }^{11}$ State Farm asks judges to invalidate agency failure to investigate reasonable alternatives or to provide an adequate justification for a particular course of action. ${ }^{12}$ It should go without saying that the State Farm framework is designed to discipline agency decisions, not to give free reign to judicial policy preferences. It is disturbing to find that whether a court of appeals is likely to find an agency decision to be "arbitrary" depends, in significant part, on whether the panel consists of Republican or Democratic appointees. ${ }^{13}$ The official doctrine opposes politicized judging; the practice plainly reveals what the doctrine explicitly opposes.

We have three purposes in this essay. The first is to set out in one place some of the most revealing evidence on politicized administrative law, with the hope that a brief overview of key findings will help to show what is wrong with the existing state of affairs. The second is to investigate a series of interpretive questions, which raise issues about how to construe the evidence, and about how seriously the current problem should be taken. The third is to explore several sets of possible remedies. One possible solution involves self-help without doctrinal change; another requires doctrinal innovations, for example through heightened deference requirements; a final one requires institutional change, for example through requiring mixed panels in certain cases.

One of the largest lessons is that while the problem of politicized administrative law is unmistakable, there are serious difficulties with each of the imaginable solutions. For example, a general increase in judicial deference to agency judgments would help to reduce politicized invalidations, but it would also remove some of the beneficial features of the current situation, in which a strong judicial hand disciplines arbitrariness at the

\footnotetext{
${ }^{9} 467$ US at 847.

${ }^{10} 463$ US 29 (1983).

${ }^{11} 5$ USC 706.

12463 U.S. at $37-38$.

${ }^{13}$ See Miles and Sunstein, supra note.
} 
agency level. ${ }^{14}$ The data suggest that mixed panels would be the best corrective, but an approach of that kind would present serious administrative challenges and also have potentially undesirable side-effects. Fortunately, some of the potential solutions would provide significant help without compromising important values.

A clarification before we proceed: Many people are concerned about the politicization of administrative law in a quite different sense from our understanding here. In their view, a serious problem lies in the role of "politics," understood as interestgroup power, over the administrative state, especially in domains in which technical expertise should prevail. ${ }^{15}$ On this view, the problem of "politicization" consists in insufficient regard for specialized knowledge. This is a legitimate and important concern, but it is an independent topic. Even if the judgments of administrative agencies sometimes reflect an excessive role for politics, in a pejorative sense, it remains important to ensure that judicial review of agency action does not radically differ depending on whether Republican appointees or Democratic appointees are on the panel. ${ }^{16}$ Our goal here is to see how that task might be accomplished.

While our focus throughout is on administrative law, we hope that our elaboration of the problem, of the interpretive issues, and of the potential solutions will bear on many areas in which judicial voting is highly politicized ${ }^{17}$ or in which public officials or others are divided along some controversial dimension or show some kind of bias. In any domain, self-help, doctrinal innovation, or institutional change might provide significant help. In some domains, one or another of these solutions might have more promise than in the context of administrative law.

\footnotetext{
${ }^{14}$ See Peter L. Strauss, Overseers or "The Deciders": Courts in Administrative Law, 75 U Chi L Rev (forthcoming 2008).

${ }^{15}$ See, e.g., Thomas McGarity and Wendy Wagner, Bending Science: How Special Interests Corrupt Public Health Research (2008).

${ }^{16}$ Recall the theoretical possibility that if agencies show a predictable skew, then some sort of skew, on the part of courts, might be necessary to ensure neutrality. The problem is that both Republican and Democratic appointees, with their disparity in votes, cannot be supplying a corrective to any skew, simply because they disagree.

${ }^{17}$ See Frank Cross, Decision Making in the Federal Courts of Appeals (2007); Cass R. Sunstein et al., Are Judges Political? (2006).
} 


\section{Politicized Administrative Law: Evidence}

\section{A. Method}

For a number of years, we have been studying judicial judgments in the domain of administrative law, in an effort to see whether those judgments reflect policy choices on the part of federal judges. ${ }^{18}$ For present purposes, our method can be simply described.

Within the courts of appeals, our focus has been on judicial review of decisions by the Environmental Protection Agency (EPA) and the National Labor Relations Board (NLRB). ${ }^{19}$ This approach has the advantage of investigating one important executive agency (the EPA) and one important independent agency (the NLRB); it also presents certain advantages in terms of coding. We attempted to categorize agency decisions as "liberal" or "conservative" by asking whether the challenge was made by a company or instead by a public interest group or a labor union. ${ }^{20}$ If, for example, the Sierra Club objected to an EPA decision, the decision was coded as conservative; if General Motors made the objection, the decision was coded as liberal. This method greatly eases the coding exercise, avoids controversial judgments that might divide reviewers, and thus improves administrability. It can also be defended in principle, because what matters is not whether the agency's decision is liberal or conservative in the abstract, but the political valence of the particular challenge before the court. Admittedly, however, our proxy is crude. For that reason, we read the cases ourselves, and when our method led to an incorrect or contestable result, we adjusted the coding accordingly. ${ }^{21}$

\footnotetext{
${ }^{18}$ See notes supra.

${ }^{19}$ In the case of agency interpretations of law, we examined all cases citing Chevron between 1990 and 2004; in the case of arbitrariness review, we examined all arbitrariness and substantial evidence cases between 1996 and 2006.

${ }^{20}$ We also studied whether the agency's decision was issued in a Republican or Democratic administration. In some domains, we found that Republican appointees are more likely to vote to uphold those of a Republican administration than those of a Democratic administration, and that Democratic appointees show a similar kind of favoritism. In Chevron cases, for example, Democratic appointees show a 70 percent validation rate under Democratic administrations and 61 percent validation rate under Republican administrations, while Republican appointees show a 59 percent validation rate under Democratic administrations and a 68 percent validation rate under Republican administration. Miles and Sunstein, supra note, at 850. In general, however, the liberal-conservative coding is a more accurate way of exploring political voting on the courts of appeals, and so that division is our emphasis here.

${ }^{21}$ If the coding produced an incorrect result (as, for example, when a public interest group challenged the agency's decision), we reversed the categorization; if coding proved difficult, the case was dropped.
} 
We also examined whether judicial votes were issued by Republican or Democratic appointees to the federal bench, with the hypothesis that the division should operate as a proxy for political predilections, and with the further thought that the effect of the political affiliation of the appointing president is of considerable independent interest. With this method, we can investigate "liberal voting rates” for Democratic and Republican appointees in different domains. We can also compare the validation rate of both sets of appointees for conservative agency decisions and for liberal agency decisions. In addition to studying the effects of party, we can study the effects of panels, by asking whether the votes of Democratic or Republican appointees are affected by the political affiliation of the president who appointed the two other judges on the panel.

The baseline case, for purposes of studying neutrality and partisanship, would show no significant disparities between Republican and Democratic appointees. If no such disparities were shown, existing administrative law doctrines would be "working” in the sense that they would be serving to filter out any effect from the most obvious and salient difference among appointees to the federal bench. And indeed, there are important areas of federal law in which partisan differences are not observed. ${ }^{22}$

For the Supreme Court, we took the same basic approach. Here, however, we examined all decisions that cited Chevron; we did not restrict ourselves to the EPA or the NLRB. And instead of distinguishing between Republican and Democratic appointees, we assessed voting patterns for each of the individual justices and (to obtain greater statistical power) for "blocks" of justices corresponding to conventional judgments about ideological divisions. With this approach, we are able to see if political predilections affect the justices' voting in administrative law cases. Because only a small number of “arbitrariness” cases reach the Supreme Court, making statistical tests impossible, we did not investigate those cases.

\section{B. Courts of Appeals: Chevron Cases}

Within the courts of appeals, politicized voting is unmistakable in Chevron cases. Consider three different ways to demonstrate this point.

\footnotetext{
22 See Cass R. Sunstein et al., Are Judges Political? 49 (2006) (finding no significant effects of party in criminal appeals, federalism, takings, punitive damages, and standing).
} 
1. When the agency's decision is liberal, the Democratic validation rate is 74 percent; when the agency's decision is conservative, the Democratic validation rate falls to 51 percent. The pattern is the opposite for Republican appointeesvery close to the mirror image. When the agency's decision is liberal, the Republican validation rate is 59.5 percent. When the agency's decision is conservative, the Republican validation rate jumps to 70 percent. $^{23}$

2. When the agency's decision is liberal, Democratic appointees are 14 percent more likely to vote to validate it than are Republican appointees. When the agency's decision is conservative, Democratic appointees are 19 percent less likely to validate it than are Republican appointees. ${ }^{24}$

3. The overall liberal voting rate is 67 percent for Democratic appointees; for Republican appointees, it is 50 percent. $^{25}$

What produces these significant disparities? Intriguingly, they are driven in large part by the radically different behavior of both sets of appointees on unified panels - that is, panels consisting solely of Democratic appointees ("DDD panels”) or solely of Republican appointees ("RRR panels”). When Democratic appointees are on DDD panels, the validation rate for liberal agency decisions is 86 percent; when Democratic appointees are on DDD panels, the validation rate for conservative agency decisions is 54 percent. $^{26}$ (This 31.5 percent percent difference should be compared with the overall difference of 23 percent. $^{27}$ ) When Republican appointees are on RRR panels, the validation rate for liberal agency decisions is 51 percent; and on such panels, the validation rate for conservative agency decision is a remarkable 100 percent. $^{28}$

Because of the relatively small sample size, the particular numbers here should be taken with a grain of salt, but they should be sufficient to show that unified panels are playing a large role in driving the results. The following point is sufficiently important to deserve italics: On mixed panels, politicized voting is greatly reduced; the behavior of Democratic appointees, on such panels, is very close to that of Republican appointees. ${ }^{29}$ In Chevron cases, the voting patterns of Rs on RRD panels is close to the voting patterns of Rs on RDD panels, and the voting patterns of Ds on DRR panels is close to that of Ds on DDR panels - and more remarkably still, all four voting patterns are close to one

\footnotetext{
${ }^{23}$ Do Federal Judges Make Regulatory Policy, supra note, at 849.

${ }^{24}$ Id at 826-27.

${ }^{25} \mathrm{Id}$ at 859 .

${ }^{26}$ Id. at 855.

${ }^{27}$ Id.

${ }^{28}$ Id. at 855.

${ }^{29}$ Id. at 863.
} 
another. ${ }^{30}$ This finding suggests that on mixed panels, Chevron is essentially working, in the sense that politicized voting is modest at best.

The dramatic difference between all-Republican and all-Democratic panels presents an obvious puzzle. Why are judicial voting patterns relatively extreme on such panels, and so much more moderate on mixed panels? We lack a complete answer, but judges appear to be influenced by the process of group polarization, which occurs when group members end up in a more extreme position in line with their predeliberation tendencies. ${ }^{31}$ Group polarization is the typical pattern within deliberating groups, and it occurs in a wide range of settings. ${ }^{32}$ If Democratic appointees show especially liberal voting patterns on panels consisting solely of Democratic appointees, it is likely because the judges' initial inclinations are amplified, rather than moderated, by learning about the conclusions and arguments of other judges. On mixed panels, by contrast, a whistleblower effect may occur, in the form of presentation of counterarguments based (for example) on the principle of Chevron deference. ${ }^{33}$ Because the initial "argument pool" is different on a DDD panel from what it is on a DDR panel, it should not be entirely surprising that Democratic appointees, on the latter kinds of panels, show relatively greater moderation. ${ }^{34}$

\section{Courts of Appeals: Arbitrariness Cases}

The pattern is strikingly similar in arbitrariness cases. Here the question is not whether the agency's decision conforms to the governing statute, but whether its judgments of policy or fact are arbitrary on the merits (or unsupported by substantial evidence). Return to our three key tests for politicized voting, and notice the closely analogous pattern in Chevron cases:

\footnotetext{
${ }^{30} \mathrm{Id}$.

${ }^{31}$ Roger Brown, Social Psychology: The Second Edition (1995); Cass R. Sunstein, Why Societies Need Dissent (2003).

${ }^{32}$ See Brown, supra note.

${ }^{33}$ Frank B. Cross and Emerson H. Tiller, Judicial Partisanship and Obedience to Legal Doctrine: Whistleblowing on the Federal Courts of Appeals, 107 Yale LJ 2155 (1998).

${ }^{34}$ There are other possible explanations. It may be, for example, that Republican and Democratic appointees vote as they would as individuals on unified panels, and that what needs explanation is the absence of politicized voting on mixed panels. On this view, group polarization is not involved; mixed panels serve to moderate judges' tendencies, and that is the key mechanism. For our purposes, it does not seem necessary to settle on a final explanation.
} 
1. When the agency's decision is liberal, the Democratic validation rate is 71percent; when the agency's decision is conservative, the rate falls to 56percent. The pattern is the opposite for Republican appointees—-very close to the mirror image. When the agency's decision is liberal, the validation rate is 58percent; when the agency's decision is conservative, the validation rate jumps to 72 percent. ${ }^{35}$

2. When the agency's decision is liberal, Democratic appointees are 13percent more likely to vote to validate it than are Republican appointees. When the agency's decision is conservative, Democratic appointees are 17percent less likely to validate it than are Republican appointees. ${ }^{36}$

3. The overall liberal voting rate is 68 percent for Democratic appointees; for Republican appointees, it is 56 percent. ${ }^{37}$

Here too, unified panels explain a significant part of these disparities. On politically unified panels of Democratic appointees, the average validation rate is 23 percentage points higher when the agency decision is liberal than when it is conservative. And on politically unified panels of Republican appointees, the average validation rate is 28 percentage points lower when the agency decision is liberal than when it is conservative ${ }^{38}$ Here as well, a form of group polarization seems to be at work. On mixed panels, by contrast, the partisan differences are greatly muted, ${ }^{39}$ perhaps because of a moderating or whistleblower effect. In those panels, existing doctrine is again "working," in the sense that judges' arbitrariness judgments do not greatly differ depending on the political affiliation of the appointing president.

\section{The Supreme Court}

1. The least and most partisan justices. The data on the Supreme Court allows individual comparisons among the Court's members. Indeed, it is even possible to rank the justices in terms of partisanship in Chevron cases. ${ }^{40}$ In this domain, it is natural to define the least partisan justices as those who show the most similar validation rates for

\footnotetext{
${ }^{35}$ Miles and Sunstein, Real World, supra note.

${ }^{36}$ Id.

${ }^{37} \mathrm{Id}$.

${ }^{38}$ Id.

${ }^{39}$ Id.

${ }^{40}$ Miles and Sunstein, Do Federal Judges, supra, at 872-880. The data set extends from 1989 to 2005, and hence Chief Justice John Roberts and Samuel Alito are not included. An effort to extend the study to the present would of course include a number of their votes, but the sample size, for those justices, would remain too small to permit reliable comparisons.
} 
liberal and conservative agency decisions. By contrast, the most partisan are those who show the largest spreads between the two validation rates.

Under this test, Justice Kennedy emerges as the least partisan of the sitting justices; he is equally likely to vote to invalidate conservative and agency decisions. ${ }^{41}$ Justice Thomas emerges as the most partisan; remarkably, he is 46percent more likely to vote to invalidate liberal agency decisions than conservative agency decisions. ${ }^{42}$ Justice John Paul Stevens is not far behind, with a stunning 40 percent difference in favor of liberal decisions. ${ }^{43}$ Consider the following table ${ }^{44}$ :

Table 1: Partisan Voting in Chevron Cases on the Supreme Court

\begin{tabular}{lcc}
\hline \hline \multicolumn{1}{c}{ Justice } & $\begin{array}{c}\text { Gap } \\
\text { ( in percentage points) }\end{array}$ & Type of Agency Decision Favored \\
\hline Thomas & 46 & Conservative \\
Stevens & 40 & Liberal \\
Scalia & 27 & Conservative \\
Breyer & 26 & Liberal \\
Ginsburg & 23 & Liberal \\
Rehnquist & 21 & Conservative \\
O’Connor & 14 & Conservative \\
Souter & 14 & Liberal \\
Kennedy & 1 & - \\
\hline
\end{tabular}

This table should of course be taken with many grains of salt. The sample size is small, and for Justices O’Connor, Souter, and Kennedy, the gap is not statistically significant (and hence they could plausibly be said to share the prize for nonpartisan voting). Moreover, it is important to examine not only the size of the gap, but also the rate of invalidation; if a justice show a large gap, but is also willing to uphold both liberal and conservative decisions at a high rate, then the problem of partisanship is diminished.

It turns out that Justice Breyer shows the highest validation rate (82 percent), ${ }^{45}$ while Justice Scalia shows the lowest (52 percent). ${ }^{46}$ The point greatly matters, because Justice Breyer's validation rate remains reasonably high for conservative decisions (64

\footnotetext{
${ }^{41}$ Id.

${ }^{42}$ Id.

${ }^{43}$ Id.

${ }^{44}$ Id.

${ }^{45} \mathrm{Id}$ at 874 .

${ }^{46}$ Id at 879 .
} 
percent), ${ }^{47}$ as does that of Justice Ginsburg (58 percent). ${ }^{48}$ By contrast, Justice Scalia’s validation rate, for liberal decisions, is a meager 42 percent. ${ }^{49}$ It emerges that the existence of a significant partisan gap may coexist with a relatively high validation rate for the "other side." Consider the following table:

Table 2: Validation Rates in Chevron Cases on the Supreme Court

\begin{tabular}{lc}
\hline \hline \multicolumn{1}{c}{ Justice } & Rate (percentage points) \\
\hline Breyer & 82 \\
Souter & 77 \\
Ginsburg & 74 \\
Stevens & 71 \\
O’Connor & 68 \\
Kennedy & 67 \\
Rehnquist & 64 \\
Thomas & 54 \\
Scalia & 52 \\
\hline
\end{tabular}

Here too, however, the individual rankings must be taken with many grains of salt. The sample size is too small to make most of the individual differences statistically significant. But it is both intriguing and suggestive to find that the four most liberal justices have the highest validation rates, while the three most conservative justices have the lowest.

2. Conservative partisans, liberal partisans. The individual rankings may be entertaining, but for purposes of understanding of operation of existing doctrine, it is more instructive to place the Court's members into groups and to examine the differences between them.

Let us compare the Rehnquist-Scalia-Thomas group with the Breyer-GinsburgSouter-Stevens group. The former group, consisting of the most conservative justices, shows a validation rate of 76 percent when the agency's decision is conservative-and a corresponding rate of just 45.5 percent when the agency's decision is liberal. ${ }^{50}$ This difference of 30.5 percent shows a remarkable effect of judicial policy preferences. The picture is not fundamentally different for the Breyer-Ginsburg-Souter-Stevens group. When the agency decision is liberal, the validation rate is 85 percent—but when it is

\footnotetext{
${ }^{47}$ Id at 874 .

${ }^{48}$ Id at 875 .

${ }^{49}$ Id at 879 .

${ }^{50} \mathrm{Id}$ at 835.
} 
conservative, the rate falls to 58percent. ${ }^{51}$ The disparity here is 27 percent, very close to that on the Rehnquist-Scalia-Thomas side. In contrast, for the two more centrist members of the court, Justices Kennedy and O'Connor, the partisan gap is small, with a 65 percent validation rate for liberal agency decisions and a 72 percent validation rate for conservative agency decisions; that seven percent difference is not statistically significant. $^{52}$

Partisan voting is readily apparent in the Supreme Court in Chevron cases, but as with individual measures, it is important to look at overall validation rates, not merely at gaps. Notably, the overall validation rate for Stevens, Souter, Breyer, and Ginsburg is 75 percent, significantly higher than the 57 percent rate for Rehnquist, Scalia, and Thomas. ${ }^{53}$ The former group votes to validate conservative agency decisions at a 58 percent rate, which is significantly higher than the 45.5 percent validation rate, for liberal agency decisions, from the latter group.

3. A brief note on politics, judicial review, and the future. In light of the existing data, we can venture some predictions about the future. Suppose that a future administration issues a range of liberal decisions (in the sense that they are challenged by regulated industries). Such an administration will be highly vulnerable before RRR panels, and will be likely to do far better before DDD panels. To the extent that the federal courts of appeals consist of a strong majority of Republican appointees, an administration that issues many liberal decisions will have special difficulty in prevailing.

Within the Supreme Court, it is also simple to predict the nature of the internal divisions. We lack enough data for Chief Justice John Roberts and Justice Samuel Alito, but at least in administrative law, it is more than mere guesswork to suggest that both liberal and conservative agency decisions, from a new administration, will produce the same kind of politicized voting, within the Court, as has been observed under recent administrations. It would not be at all surprising to find, for example, that a new Democratic administration would suffer a number of losses in the Court, at least if Chief Justice Roberts and Justice Alito show the anticipated voting patterns, and if Justice Kennedy joins them a significant percentage of the time.

\footnotetext{
${ }^{51}$ Id.

${ }^{52} \mathrm{Id}$.

${ }^{53} \mathrm{Id}$
} 


\section{Five Matters of Interpretation}

At first glance, the most important lesson is plain: Judicial review of administrative action shows a strong effect from the political inclinations of federal judges. In the abstract, this lesson is not exactly stunning. The problem is that existing administrative law principles are best understood as a self-conscious effort to prevent this state of affairs. Under Chevron, courts are supposed to invalidate agency interpretations of law only if the governing statute is clear or if the interpretation is unreasonable. ${ }^{54}$ The doctrine and the practice sharply diverge, because the doctrine is an effort to prevent the kinds of disparities now observed on both the Supreme Court and the courts of appeals. And as the Court understands the "arbitrary or capricious” standard, agency judgments of policy and fact are to be invalidated if they are unreasonable or senseless, not because they run afoul of judicial policy preferences. ${ }^{55}$ Here too the doctrine and the practice sharply diverge, at least on the courts of appeals, where statistical tests are possible.

The partisan voting patterns seem to call out for some kind of remedy. But of course the evidence is not simple to interpret. Consider five difficulties.

\section{A. Who's Partisan?}

Begin with voting patterns on the Supreme Court. Is it altogether clear that Justices Thomas and Stevens are the most partisan, or that the two opposing "blocks" show high (and nearly equivalent) levels of partisan voting? A skeptic would insist that in order to answer that question, we cannot simply stare at the numbers. ${ }^{56}$ We also need to know something about the merits-about whether agencies are actually interpreting statutes correctly. If, for example, liberal agency decisions are more likely to be inconsistent with the statutory text, then Justice Scalia and Thomas, who seem to show a significant partisan "skew" in their voting patterns, might be neutral in their practice, whatever the numbers suggest. Or if conservative agency decisions are more typically inconsistent with the law, then Justice Stevens might be the nonpartisan one

\footnotetext{
${ }^{54} 467$ US at

${ }^{55}$ See State Farm, supra, 463 US at 47-50.

${ }^{56}$ This point is put in a broader context in a highly instructive essay, Eric Posner, Does Political Bias in the Judiciary Matter? Implications of Judicial Bias Studies for Political and Legal Reform, U. Chi L Rev (forthcoming 2008).
} 
notwithstanding the 40 percent gap reflected in his voting pattern. The various rankings assume that liberal agency decisions and conservative agency decisions are equally likely to be inconsistent with the law. Is this correct?

The same point holds for the courts of appeals. It is true that Republican appointees are more likely to uphold conservative agency decisions than liberal ones and that Democratic appointees show the opposite pattern. But to evaluate this finding, it would be important to learn about the EPA and NLRB decisions in the relevant period. Perhaps political voting is limited to one or another side; perhaps Republican appointees or Democratic appointees are simply applying the law.

Even if this objection turns out to be valid, the problem of partisan voting remains; the only qualification would be that such voting would be limited to one or another set of judges. Moreover, it is unlikely that the objection is valid, at least in its most ambitious forms. Neither the Supreme Court nor the courts of appeals reviews all EPA and NLRB decisions, or even a majority of them. Within the Court, the sample is generally limited to cases that are both important and difficult, and to be seen as worth litigating by both sides; in such cases, a consistent error rate, from one or another side, would be a surprise. Within the lower courts, reasonable arguments are usually made on behalf of the competing views. From our own reading of the cases, it does not seem that liberal agency decisions or conservative ones are systematically more likely to be in violation of the governing statute (or the clear text) or arbitrary as a matter of fact or policy. To be sure, a careful investigation of the merits might require some amendments of the basic account we are offering, but the significant differences in voting patterns are most unlikely to be understandable in terms that neglect the political predictions of federal judges.

\section{B. How Large a Problem?}

It is legitimate ask about the magnitude of the problem. If Republican appointees showed a 10 percent liberal voting rate and Democratic appointees a 90 percent liberal voting rate, we might well be alarmed. But the overall partisan difference is far smaller than that -17 percent in the Chevron cases and 12 percent in the arbitrariness cases. Is that difference large enough to justify reforms or even substantial concern? It is clear that 
Democratic appointees are voting in favor of companies and against public interest groups in a large percentage of cases (about one-third of the time in the entire data set) and that Republican appointees are often voting in favor of public interest groups and against companies (over two-fifths of the time in the entire data set). Far more often than not, the two sets of judges are in accord. Is there a serious problem to be solved?

This question might be pressed with special concern by those who emphasize the selection of cases for litigation. ${ }^{57}$ People (and their lawyers) are unlikely to challenge agency action unless they have a significant chance of success. Most of the time, agencies are unlikely to proceed in the first instance unless they have a plausible legal basis for doing so. The cases studied here represent a small sliver or band of imaginable disputes, consisting only of those agency decisions that litigants are prepared to challenge and that agencies are prepared to defend. In such cases, even a significant disparity between Republican and Democratic voting patterns should not be taken as politics run rampant.

The point is correct. But it should not be overstated. The disparity remains highly significant. And in one sense, our estimates understate the actual influence of ideology, for the very reason that we have been exploring. When an agency must defend a liberal decision before a conservative court, it is more likely to settle, and conversely, when an agency must defend a conservative decision before a liberal court, it is more likely to settle. ${ }^{58}$ The observed court decisions are therefore drawn from cases in which settlement is less likely, and the set of observed decisions does not encompass these cases (we do not know exactly how many there are) in which the judicial outcome would likely be predictably ideological. Were we to observe a counterfactual world in which all cases proceeded to trial, the observed decisions would include a somewhat larger share of (and thus a high rate of) predictably ideological judicial decisions.

The most important point is that it remains true that notwithstanding the evident aspiration of both Chevron and State Farm, politicized voting patterns are unmistakable in the federal courts. Recall that in Chevron cases, a Democratic appointee on a unified panel is 31.5 percent more likely to vote in favor of liberal agency decisions than

\footnotetext{
${ }^{57}$ For discussion, see Miles and Sunstein, supra note.

${ }^{58}$ We acknowledge that the incentives for settlement are probably weaker for agencies than for ordinary litigants. The financial pressures that induce private litigants to settle apply more weakly to the NLRB and the EPA, and both agencies often have strong reason to defend their orders and their rules. Nonetheless, settlements do occur.
} 
conservative agency decisions - and that a Republican appointee on a unified panel is 40 percent more likely to vote in favor of conservative agency decisions than liberal agency decisions. The consequence is that important agency decisions are struck down, or validated, when a different result would obtain on a mixed panel. And if an NLRB order or EPA rule is invalidated by a DDD or RRR panel, the invalidation will usually be final. In a system committed to the rule of law, to impartial justice, and to similar treatment of the similarly situated, this is a serious problem.

\section{Ex Ante vs. Ex Post}

Empirical tests can easily study decisions ex post, to see what kinds of voting patterns are displayed by federal judges. But an important question, and perhaps an even more fundamental one, involves the ex ante incentives imposed on federal agencies. On an optimistic account, the situation is far better ex ante than ex post.

As things now stand, agencies can be seen to face a kind of lottery. Within a certain range, their decisions will certainly be upheld, no matter the composition of the panel; and if the agency plainly violates the statutory text or acts in a patently arbitrary way, its decision will be invalidated, regardless of who sits on the reviewing court. And across a certain space of alternatives, there will be some uncertainty, with a range of probabilities of invalidation, depending on the composition of the panel. In that range, the agency's lawyers might be prepared to conclude that the relevant decision can be plausibly defended. Within a certain domain of that range, the lawyers might be able to add that the decision is more likely than not to be upheld in court. But they might be prepared to acknowledge, if pressed, that the likelihood of validation is well above 50 percent before a panel consisting solely of Republican appointees and well below 50 percent before a panel consisting solely of Democratic appointees.

In these circumstances, how will the agency proceed? To answer that question, we need to know something about the weight given by the agency to the prospect of invalidation, and about the agency's attitude toward risk. Exactly how much does the agency care about surviving judicial review? And is the agency risk-averse or riskinclined? The agency will face a probability distribution, and it will act in accordance with the perceived risks. Suppose that the agency cares a great deal about ensuring validation and also that the agency is risk-neutral. Or suppose that the agency does not 
greatly care about ensuring validation (perhaps because what matters, for political reasons, is issuing the rule in the first place) and that it is risk-seeking. If the risk of invalidation is 60 percent before an all-Democratic panel, but 35 percent before an allRepublican panel, an agency can make the relevant calculations and proceed accordingly. The overall likelihood of invalidation, given all the possible panel compositions, might be 40 percent; and the agency might proceed as it would, in the face of that risk, even if every possible panel was 40 percent likely to invalidate its decision. The key point is that whatever the disparities across panels, there is an overall likelihood of invalidation, and the agency can act with that figure in mind, just as it would without such disparities. From the ex ante point of view, then, what is the problem with politicized voting?

This is a legitimate question, but even if it is fundamentally right in its own terms, three potential problems remain. The first is that the panel lottery faced by agencies may not be a fair game. If the composition of the federal courts were disproportionately Republican (or Democratic), an agency would not have an equal probability of facing a DDD and an RRR panel. A politically unbalanced judiciary, as distinguished from a politically unbalanced panel, implies shifts in the range of decisions that an agency can expect will be validated. To continue the example above: If the risks of invalidation before all-Democratic and all-Republican panels remain unchanged, but the incidence of all-Democratic and all-Republican panels change, the expected likelihood of invalidation might rise from 40 percent to 60 percent. Or it might fall to 20 percent. Of course it remains true that ex ante, agencies can calculate (if only roughly) the likelihood of invalidation. But the movement in the expected chance of invalidation is troubling because it indicates that whether an agency action is lawful will partly depend on the expected judicial composition of the reviewing court. ${ }^{59}$

Second, politicized voting by panels may influence the amount of resources an agency invests in rendering decisions and defending them in court. ${ }^{60}$ If the risk of a politicized invalidation is high, and if the agency is risk-averse, it is likely to increase its efforts to demonstrate the validity of its action. To the extent that the agency expends

\footnotetext{
${ }^{59}$ To the extent that the composition of the federal judiciary, at any given time, reflects a well-functioning political process, with appropriate constraints on judicial discretion, this concern is admittedly alleviated. See Posner, supra note, for relevant discussion.

${ }^{60}$ On this problem in general, see Thomas McGarrity, Some Thoughts on De-Ossifying the Rulemaking Process, 41 Duke LJ 1385 (1992).
} 
additional resources bolstering its decision, it invests more than it would have if it had anticipated facing a less politicized regime of administrative law. These additional resources of course delay agency action, perhaps (in the case of the EPA) sacrificing human health, and they also have an opportunity cost. The additional resources are drawn away from other activities that the agency would otherwise pursue. Defense of a clean-air regulation may come at the expense of creating a clean-water regulation. For resourceconstrained agencies_-as surely all agencies are — the possibility of a politicized panel could distort an agency’s allocation decisions. ${ }^{61}$

Third, politicized voting by panels may affect the content of agency decisions. An agency may decide in good faith that a particular policy is lawful and would be highly desirable. But if the risk of a politicized invalidation is very high, the agency may decide that the resources required to establish the validity of the policy before a potentially hostile court are too great. The agency may then modify the decision to make it more palatable to the expected panel but at the cost of a reduced improvement in social welfare. Or the agency may choose to forgo the decision altogether. ${ }^{62}$ In either case, politicized review would result in the agency's refusal to proceed with a socially beneficial decision. There is ample evidence that effects of this sort do in fact occur. ${ }^{63}$

In any case, the ex post perspective matters as well. If important EPA rules are invalidated by all-Democratic panels, while they would be upheld by all-Republican panels, similarly situated litigants will be treated differently, in a way that ensures that the meaning of federal statutes turns on a kind of lottery. If NLRB decisions are won by unions before DDD panels, but by companies before RRR panels, something is seriously amiss. Even if the current regime does not have significantly different incentive effects from one with less politicized voting, it does serious violence to the rule of law, and it has a significant effect on ultimate outcomes.

\footnotetext{
${ }^{61}$ Naturally, the argument works the other way for politicized voting that favors an agency. An increase in the chance that an agency faces a friendly reviewer may reduce the resources an agency spends in establishing the validity of its decision, and this may be undesirable when closer inquiry is warranted.

${ }^{62}$ See McGarrity, supra note.

${ }^{63}$ The best discussion remains Jerry Mashaw and David Harfst, The Struggle for Auto Safety (1990) (discussing effects of aggressive judicial review in discouraging agency rulemaking).
} 


\section{Invalidations or Validations?}

An independent question is whether the best reading of the evidence emphasizes politicized invalidations. We have seen that the Republican invalidation rate jumps when the agency decision is liberal, and the Democratic invalidation rate jumps when the agency decision is conservative. These points suggest that agencies are probably losing many cases that they ought to win. But it is possible that what has been uncovered is politically motivated validations. Perhaps the real story is the relatively low invalidation rate when Republican appointees review conservative regulations and when Democratic appointees review liberal ones. Perhaps conservative decisions are being wrongly validated before all-Republican panels; perhaps liberal agency decisions are being wrongly validated before all-Democratic panels. Indeed, it is possible, in light of the data, that the more serious problem consists of excessive numbers of validations.

This point is indeed consistent with the evidence, and it has important implications for possible responses. We will return to the question below.

\section{E. Second-Order Diversity}

Sometimes it is desirable to have diversity within institutions—as, for example, in the context of national legislatures. But sometimes it is desirable to have diversity across institutions-as, for example, in a situation in which Massachusetts attempts some educational reforms and Utah ventures others, or different law schools or economics departments develop different "schools." Heather Gerken has written illuminatingly of

the idea of "second-order diversity," a degree of internal unity, produce a kind of diversity from which society as a whole might benefit. In some cases, second-order diversity should be the goal, not first-order. If society is able to learn a great deal from institutions that are internally unified but different from one another, and if those institutions do not do much damage to anyone, then second-order diversity might be better than its first-order cousin.

In administrative law, we can find a high degree of second-order diversity, made possible by unified panels. Might this be desirable? Consider the following account. With

\footnotetext{
${ }^{64}$ See Heather Gerken, Second-Order Diversity and Disaggregated Democracy, 118 Harv L Rev 1099 (2005).
} 
unified panels, a large number of ideas will inevitably make their way onto the pages of federal court opinions. RRR panels will offer distinctive interpretations of the Clean Air Act or the National Labor Relations Act; DDD panels will offer distinctive interpretations of their own. Perhaps the legal system benefits from this level of diversity. When courts of appeals are divided, the Supreme Court will ultimately decide, with the benefit of the additional information provided by a wide array of views within the lower courts.

In some domains, this defense of second-order diversity, within the federal courts, has a great deal of plausibility. In constitutional law, for example, the system as a whole probably benefits from RRR and DDD panels, which produces a range of disparate analyses of issues involving the Second Amendment, abortion, affirmative action, campaign finance regulation, and much more. The Supreme Court and the culture as a whole benefit from such analyses. But the defense is far less plausible in the context of administrative law. We have emphasized that in almost all of the relevant cases, the decision of the court of appeals is effectively final, because the Supreme Court hears only an exceedingly small percentage of them, and many turn on complex issues of fact or policy or on relatively technical issues of statutory construction. If an RRR panel concludes that the NLRB improperly found the facts, and rules in favor of a company challenging a finding of an unfair labor practice, or if a DDD panel rejects the EPA's interpretation of the Clean Air Act in favor of that offered by the Sierra Club, the likelihood of some social benefit from a hypothetical increase in "diversity" is very low. In these circumstances, it is not easy to defend the status quo by reference to the interest in second-order diversity.

\section{Solutions}

Let us now turn to three sets of solutions. The first involves self-correction without doctrinal change, brought about by judges' own understanding of the problem of politicized administrative law. The second set includes doctrinal responses, taking the form of new developments involving the governing legal principles. The third and most ambitious set involves institutional innovation, as, for example, through voting rules or requirements of mixed panels. 


\section{A. Self-Correction}

1. Knowledge as corrective, sunlight as disinfectant. Some of the evidence catalogued here should be taken as highly embarrassing to the federal judiciary. Most federal judges would not like to think that in reviewing agency action, their voting patterns show a significant influence from the party affiliation of the president who appointed them. Perhaps a better understanding of the situation could provide a safeguard against politicized voting. On an optimistic view, awareness of the underlying patterns might provide a degree of help; it might even produce a form of “debiasing." Justice Louis Brandeis famously said that "sunlight is the best of disinfectants." "65 Perhaps a little sunlight, with respect to voting patterns, might induce a degree of self-consciousness and self-scrutiny, thus reducing politicized voting. At the very least, the data suggest that judges on unified panels should be cautious about behaving in a way that fits with partisan predictions.

This is certainly possible, but there is no reason for great confidence in this prospect. It is an understatement to say that most judges do not spend a great deal of time reading academic work, and in most cases, studies of judicial behavior are not likely come to their attention. And even if some judges become aware of relevant studies, a significant effect on their behavior would be surprising. No one should doubt that judges act in good faith, and when they vote to strike down or to uphold agency action, they are behaving in accordance with the law as they understand it. It is relevant in this regard that members of the Supreme Court are the judges subject to the most persistent public scrutiny-yet they too show highly politicized voting patterns. Perhaps an improved understanding of the degree of politicized voting could produce some good, but it is unlikely to make a significant contribution to solving the problem.

2. Warning flags and reviewing the reviewers. A mildly more aggressive response would be to suggest that when a DDD panel or an RRR panel goes in the expected direction, a warning flag has been raised, one that justifies some form of oversight and review. Suppose, for example, that a RRR panel has struck down some regulation from the EPA, accepting a company's claim that the regulation is arbitrary or in violation of the governing statute. If the EPA seeks en banc or Supreme Court review, there is special

\footnotetext{
${ }^{65}$ See Louis Brandeis, Other People’s Money (1914).
} 
reason to take the request seriously. Or if a DDD panel has acted in a predictable fashion in an important case involving the NLRB, and the NLRB seeks certiorari, the Court has an additional reason to wonder about whether the panel might have erred.

To be sure, there are evident risks with giving a great deal of weight to panel composition. What matters is the court's conclusion and analysis, not the political affiliation of the appointing president. At the same time, the existence of a unified panel, reaching the expected conclusion, does provide a clue that the conclusion and the analysis might be skewed. Indeed, it is likely that judgments about en banc review, and about whether to grant certiorari, are sometimes influenced by an appreciation of the composition of the panel. ${ }^{66}$

But this response would be at best a partial response to the current situation. It would impose on agencies the potentially considerable costs of appeal, an expense that would be spared if politicized decisions were avoided in the first instance. En banc review is necessarily rare, and agencies seek Supreme Court review infrequently, especially when their decision is invalidated as arbitrary or capricious; such invalidations depend on particular facts and are most unlikely to attract the Court's attention. ${ }^{67}$ Even when agencies appeal, as we have seen that the Supreme Court grants certiorari in only a small fraction of cases. A warning flag may well be appropriate, but it cannot suffice to eliminate politicized voting.

3. Political rankings. We have ranked Supreme Court justices in terms of politicized voting, and it would be possible to far more systematic in this vein, covering lower courts as well. Rankings might increase the transparency of the current situation, which serve as a significant deterrent to politicized voting patterns.

At the same time, judicial rankings are unlikely to provide much of solution. They might not come to the attention of judges at all. They may distract judges from rendering decisions in accordance with law and encourage them to burnish their public perception as neutral. They may erode public confidence in courts to the extent that they reinforce a skeptical view, not at all supported by the evidence, that law is always politics in the

\footnotetext{
${ }^{66}$ There is an important empirical project to be done here: Are unified panels in fact more likely to be subject to en banc and Supreme Court review? To reversals?

${ }^{67}$ Robert J. Hume, Administrative Appeals to the U.S. Supreme Court: The Importance of Legal Signals, 4 J Empirical Legal Stud 625, 644-45 (2007).
} 
crudest sense. Finally, the statistics underlying any rankings are likely to be crude, failing to capture important dimensions of judicial decisionmaking. ${ }^{68}$

\section{B. Doctrinal Solutions}

1. Rethinking Mead. Chevron was intended to eliminate the role of judicial policy judgments from review of agency inaction; it has failed to do so. At the same time, the Court has retreated, in significant ways, from the Chevron framework, by reducing the level deference in certain classes of cases. A relatively modest doctrinal response to the situation described here would be to rethink the Court's most serious retreat, in United States v. Mead, ${ }^{69}$ on the ground that it has a serious unanticipated side-effect, which is to increase the politicization of administrative law.

To make a long and complex story too short and simple, ${ }^{70}$ Mead draws a distinction between two kinds of deference to agency interpretations of law. The stronger form of deference, reflected in Chevron itself, applies when agencies have exercised delegated authority to make rules or to promulgate orders. The weaker form of deference, reflected in Skidmore, ${ }^{71}$ may apply when agencies have not exercised such authority. An apparent rationale of Mead is that if agencies have gone through rulemaking procedures or through the adjudicative process, there is some guarantee of fairness and deliberation, in a way that justifies heightened deference. ${ }^{72}$ But if agencies have not gone through the relevant processes, perhaps the risk of unfairness or unreasonableness is heightened, in a way that justifies a firmer judicial hand.

The distinction between Skidmore and Chevron raises many complexities, and the doctrine is producing a great deal of confusion in the lower courts. ${ }^{73}$ Intuition and common sense suggest another problem: There is reason to think Skidmore review, authorized by Mead, may well ensure not a firmer judicial hand, but a situation in which judicial policy preferences play a (still) larger role than they do under Chevron. To

\footnotetext{
${ }^{68}$ See the discussion of interpretive difficulties, supra.

${ }^{69}$ US v Mead, 533 US 218 (2001).

${ }^{70}$ For details, see Cass R. Sunstein, Chevron Step Zero, 92 Virginia L Rev 187 (2006).

${ }^{71}$ Skidmore v. Swift \& Co., 323 US 134 (1944). An exceedingly valuable empirical study is Kristin Hickman and Matthew Krueger, In Search of the Modern Skidmore Standard, 107 Colum L Rev 1235 (2007).

${ }^{72}$ Mead, supra note.

${ }^{73}$ See Adrian Vermeule, Mead in the Trenches, 71 GW L Rev 237 (2003).
} 
evaluate this speculation, a great deal of empirical work would be necessary. But if Chevron has at least some kind of disciplining effect on judicial policy judgments, then Mead is likely to increase politicization.

What does current evidence show? A noteworthy fact: On the Supreme Court itself, politicized voting does not seem to be greater under Skidmore than under Chevron. The Stevens-Souter-Breyer-Ginsburg group shows a 27 percent greater willingness to validate liberal agency decisions than conservative agency decisions under Chevron; the corresponding figure is 23 percent under Skidmore. ${ }^{74}$ The Rehnquist-Scalia-Thomas group shows a 30 percent greater willingness to validate conservative agency decisions than liberal agency decisions under Chevron; the difference is 37 percent under Skidmore. $^{75}$ Neither of these differences is statistically significant. We do not know whether greater differences would be found on the lower courts; the issue would be well worth investigating. But it is possible that the use of Skidmore, rather than Chevron, does not create more in the way of politicized voting. The more general point is that politicized voting remains high under Chevron, and hence the doctrinal shift from Skidmore to Chevron would not be likely to do a great deal about the real problem.

2. Increased deference. (a) The central idea. A natural response to the data would be to argue for increased deference, or a kind of "super-Chevron," in judicial review of agency interpretations of law and judicial review of agency judgments of policy and fact. If Republican appointees are invalidating liberal agency decisions at a high rate, and if Democratic appointees are invalidating conservative agency decisions at a high rate, then we might want more deferential review from both sides. If the evident aspiration of Chevron has failed, there seems to be strong reason to reduce the intensity of judicial review of agency interpretations of law. And if arbitrariness review is being conducted in a way that shows a significant effect from judicial policy preferences, then the most obvious response would be to reduce the intensity of such review. What is now a "hard look" on the part of reviewing courts might be transformed into a "soft look."

There are, however, three objections to this recommendation. ${ }^{76}$

\footnotetext{
${ }^{74}$ Miles and Sunstein, supra note, at 846.

${ }^{75}$ Id.

${ }^{76}$ A possible doctrinal solution, in some domains, would be to prefer rules over standards. It has been shown that this approach can serve to reduce the effects of judicial ideology. See Adam Cox and Thomas J.
} 
(b) Objections. The first is that a degree of politicization may be a necessary price to pay for forms of judicial review that have otherwise desirable consequences. Increased deference may, for example, eliminate a valuable ex ante deterrent to careless or arbitrary decisions at the agency level. ${ }^{77}$ The benefits of that deterrent effect may outweigh the costs of politicized review. We have seen that in a sense, agencies face an ex ante "policy lottery” once their decisions are challenged, because they cannot know whether the panel will be RRR, DDD, RRD, or DDR. Other things being equal, the existence of that lottery is likely to ensure better decisions, simply because of a certain probability of invalidation. The point applies both to agency interpretations of law and agency judgments of policy and fact. In both cases, agencies are likely to be disciplined by the existing standards of review. To put the point another way: The correlations between judicial ideology and validation rates do not demonstrate that all things considered, the current doctrinal balance between judicial ideology and agency error is the wrong one. Even if we could reduce those correlations, we might not be satisfied, because the risk of agency error might increase.

The second objection is that statistical patterns of the sort described here might rematerialize even with increased deference. Indeed, reduced deference might produce precisely the same patterns. After a decision to strengthen the lesson of Chevron, new empirical research might discern politicized voting of the same level that we have reported here. The reason is that litigants should be expected to adjust their behavior to the existing standard of review. ${ }^{78}$ If deference were increased, some cases would not be brought that were brought before the increase, and the level of validation might therefore remain identical. And in the (by hypothesis close) cases that were brought under the new standard, political judgments might inevitably play a role, producing disparities of the sort we have described. In fact we might even venture an Invariance Hypothesis: Because litigants adjust their behavior to the existing standard of review, the level of validations and the degree of politicized voting will be unaffected by that standard.

Miles (forthcoming 2008). In the context at hand, however, it is difficult to see how this solution might be made to work.

${ }^{77}$ William F. Pederson, Jr., Formal Records and Informal Rulemaking, 85 Yale L J 38, 60 (1975) ("It is a great tonic to a program to discover that even if a regulation can be slipped or wrestled through various layers of internal or external review [inside the bureaucracy] ... the final and most prestigious reviewing forum of all—a circuit court of appeals—will inquire into the minute details of methodology.”)

${ }^{78}$ Miles and Sunstein, supra note. 
It is not clear that the Invariance Hypothesis is correct. ${ }^{79}$ If judicial review were entirely unavailable, of course, there would be no politicized voting. But if judicial review were available but exceptionally deferential, is it obvious that the rate of validation and politicized voting would remain constant? The answer depends on the responsiveness of litigants and agencies to changes in the scope of review. If neither litigants nor agencies are highly responsive, we should expect that increased deference would increase validation rates and decrease politicized voting. If litigants are highly responsive, but agencies are not, we might expect that increased deference would have little effect. However we analyze the details, the general objection is straightforward: An increase in deference might have little or no effect on politicized voting.

The best response to this objection is that even if the statistics remain the same, the politicized voting is in an important sense less damaging, because with greater deference, agencies are given greater room to maneuver from Republican appointees and Democraric appointees alike. A softening of review should ensure that political differences among the two sets of appointees would have a correspondingly smaller effect on ultimate outcomes. Even if the statistical analysis looks the same, the softening would ensure a reduced effect from politicized voting.

The third objection is that the real problem may be politicized validations, not politicized invalidations, and if this is so, then more deferential review would seem perverse. As we have suggested, nothing in the evidence outlined here demonstrates that the level of invalidations is too high. The real story may be the deferential approach of RRR panels to conservative agency decisions and of DDD panels to liberal agency decisions. If this is so, then a softening of review may be highly undesirable, because it would increase the level of deference of RRR and DDD panels to decisions to which they are already too deferential.

(c) Evaluation. It emerges that a general increase in deference should reduce disparities in politicized invalidations. To that extent, it would indeed be responsive to a plausible reading of the evidence sketched here. But the price of this gain may be too large; to answer that question, we need to know more about what is gained and what is

\footnotetext{
${ }^{79}$ For discussion, see id.
} 
lost. And for those who are concerned about politically motivated validations, increased deference would sacrifice a great deal.

We are left with the conclusion that both RRR and DDD panels should be careful about both validations and invalidations that square with their predicted inclinations, but with an understanding that a softening of judicial review is not fully justified by, or an adequate response to, evidence of politicized voting. Our own conclusion, admittedly not compelled by the data, is that some softening of review would be warranted, because politicized invalidations are the most serious problem. Most of the time, we believe that it is more troublesome if courts are striking down agency action than upholding it, because the political process contains a range of safeguards against arbitrary or unlawful action in the first instance. But we acknowledge that by itself, the evidence outlined here is not sufficient to justify this conclusion.

\section{Institutional Solutions}

Perhaps the best solution does not involve self-help or doctrinal change; perhaps it is institutional. But what form would an institutional solution take? We can imagine several possibilities.

1. Clearer statutes. If Congress spoke unambiguously, partisan voting should not be anticipated, because all judges would agree about statutory meaning. Recall that in most administrative law cases in the data set, Republican and Democratic appointees already do agree. Certainly in a regime governed by Chevron, truly unambiguous statutes would not produce divisions between RRR and DDD panels. Indeed, truly unambiguous statutes would not need Chevron to squelch those divisions. Perhaps the lesson of politicized judicial voting is simple: Congress should legislate more clearly.

But there are two problems with this solution, one small. A small one is that because of the selection effect, politicized voting should be expected in those cases that end up being litigated. This is a small point because even if we see such voting, it would be along a modest margin; the stakes would be lowered. The larger point, a subject of an elaborate literature, is that there are formidable objections to the idea that Congress should enact clearer statutes. In many cases, Congress lacks the information to legislate with particularity, and greater specificity would likely diminish social welfare rather than 
increase it. ${ }^{80}$ Greater specificity on Congress' part may well ensure that congressional committees, some of them highly susceptible to interest-group power, would be responsible for the content of federal law. ${ }^{81}$ It is true that unambiguous legislation would reduce politicized voting, but it would also have a series of undesirable consequences. As a solution to the troublesome judicial voting patterns sketched here, clearer legislation would be excessively ambitious.

2. Supermajorities. Might voting rules help? In an illuminating essay, Jacob Gersen and Adrian Vermeule argue that the goals of the Chevron approach might be implemented, not through doctrine, but through a special voting rule. ${ }^{82}$ Suppose that agency action could not be struck down, under the Chevron framework, unless all three judges supported that result. At first glance, a unanimity requirement would seem to reduce the likelihood of politicized invalidations. It follows that if the goal is to depoliticize administrative law, a voting rule might do far better than doctrinal innovation. And if judicial review of agency action for arbitrariness shows a political slant, a voting rule would appear to be a sensible solution. Perhaps agency action should not be invalidated as arbitrary unless all three judges, on a three-judge panel, can be persuaded to vote for invalidation. Of course there are serious political obstacles to a change of this nature; unanimity is not required in other domains of federal law. But if unanimity would eliminate the problem of politicized administrative law, it would be worth serious consideratin.

In some domains, a special voting rule would undoubtedly make a great deal of sense as a safeguard against partisan voting. Unfortunately, the data suggest a large objection to this approach, at least if it is intended as response to politicized voting in administrative law. As we have seen, the most serious problem comes on RRR and DDD panels; it is on such panels, which are almost always unanimous, that the most politicized voting can be found. On RRD and RDD panels, the role of politics is limited and even hard to detect. The conclusion is simple: In light of the current evidence, a unanimity

\footnotetext{
${ }^{80}$ See Eric Posner and Adrian Vermeule, Interring the Nondelegation Doctrine, 69 U Chi L Rev 1729 (2002).

${ }^{81}$ See David Epstein and Sharyn O’Halloran, Delegating Powers (1999).

${ }^{82}$ See Jacob E. Gersen and Adrian Vermeule, Chevron as a Voting Rule, 116 Yale LJ 276 (2007).
} 
requirement would provide help where no help is required, and would provide no help where help is greatly needed.

It emerges that the Gersen/Vermeule proposal would not solve the problem of politicized administrative law. And for those who are most concerned about the possibility of politically motivated validations, a voting rule, of the sort that Gersen and Vermeule recommend, would seem perverse. Perhaps their proposal could be turned on its head so as to require unanimity to uphold rather than invalidate agency action; but it is an understatement to say that approach would present problems of its own.

3. Mixed panels. Much of modern adjudication is undertaken by federal administrative agencies. Indeed, the National Labor Relations Board, the Securities and Exchange Commission, and the Federal Communications Commission do much of their business via adjudication. By federal statute, these and other agencies must have mixed compositions, in the sense that no more than a bare majority of their members may come from a single political party. ${ }^{83}$ The requirement of mixed composition seems to have a significant effect. Recent evidence shows that the partisan affiliation of board members predicts their votes and that mandated bipartisan composition matters within these agencies. ${ }^{84}$ Building on these precedents, we might be tempted to suggest that federal courts of appeals would do better, in many domains, if they had mixed compositionsand that in certain high-stakes cases, at least, mixed compositions might be mandated. ${ }^{85}$

As a direct response to politicized voting, there is a great deal to be said on behalf of panels of mixed composition. If DDD and RRR panels are the most serious problem, then that problem would appear to be solved by ensuring against unified panels. But a requirement of mixed panels would run against long traditions and would create both administrative and symbolic problems; there may be pragmatic objections as well. Assignment to three-judge panels is now random, and it would be quite complicated to take steps to ensure that all such panels, in administrative law cases, have both

\footnotetext{
${ }^{83}$ See, eg., 15 USC 78d(a) (requiring bipartisan composition of SEC).

${ }^{84}$ Daniel E. Ho, Congressional Agency Control: The Impact of Statutory Partisan Requirements on Regulation, Stanford Law School working paper (February 12, 2007) (reviewing the empirical literature and finding that partisan affiliation of F.C.C. commissioners correlates with voting patterns, even after controlling for the party of the appointing president).

${ }^{85}$ See also Emerson H. Tiller and Frank B. Cross, A Modest Proposal for Improving American Justice, 99 Colum L Rev 215 (1999) (calling for mandating politically mixed panels rather than pure random assignment).
} 
Democratic and Republican appointees. Any effort, by Congress, or courts themselves, to move in this direction would undoubtedly run into serious political obstacles. In addition, judges are supposed to leave their political commitments behind once they become judges, and a requirement of mixed panels might seem objectionable insofar as it would be an acknowledgement that political commitments matter to judging. That acknowledgement might entrench the very problem that it is intended to reduce. Perhaps both Republican and Democratic appointees would come conceive of themselves, to a somewhat greater degree than they now do, as political partisans, simply because the requirement of mixed composition would suggest as much.

The question, then, is whether the problem of politicized administrative law is severe enough to justify strong medicine of this kind. We think that the answer may be affirmative, at least in cases in which the stakes are especially high. In such cases, the chief judge of the relevant circuit might consider adopting a general practice of calling for mixed panels. ${ }^{86}$ The issue is whether other, less aggressive responses can provide adequate safeguards.

\section{Conclusion}

In the recent period, administrative law has been highly politicized in the sense that the voting patterns of Republican appointees are significantly different from the voting patterns of Democratic appointees. The politicized patterns are strikingly similar in Chevron cases and in arbitrariness cases. In both domains, federal judges show especially politicized voting patterns on unified panels, where the disparities between Republican and Democratic appointees are very large. On the Supreme Court itself, many of the justices show an ideological "skew" in their application of the Chevron framework.

It is clear that no one should be happy about this state of affairs. It is much less clear what should be done about it. Sunlight is often a disinfectant, and perhaps a broader knowledge of recent patterns will supply a kind of corrective; we have suggested that "rankings" of judges, in terms of politicization, might provide some help. There is certainly reason for greater skepticism about court of appeals decisions when unified

\footnotetext{
${ }^{86}$ Because of its great importance to administrative law and federal regulation, the United States Court of Appeals for the District of Columbia Circuit is the best candidate here.
} 
panels reach a conclusion that fits with their expected predilections. Doctrinal changes, calling for heightened deference to agency action, would decrease the likelihood of politicized invalidations. The largest lesson is that there is more reason to trust the outcomes of mixed panels than the outcomes of unified panels. Whether mixed panels should be required, in the most important cases, is not a question that the evidence alone can answer; but it is a question that the evidence makes it reasonable to ask. Our largest hope is that an understanding of politicized administrative law, and of possible responses, will bear on many domains in which federal judges are divided along predictable lines, and indeed other domains in which entrenched differences, and potential biases, create potential difficulties for both private and public institutions.

Readers with comments should address them to:

Professor Thomas Miles University of Chicago Law School

1111 East 60th Street

Chicago, IL 60637

tmiles@uclaw.uchicago.edu 


\section{Chicago Working Papers in Law and Economics (Second Series)}

For a listing of papers 1-299 please go to Working Papers at http://www.law.uchicago.edu/Lawecon/index.html

300. Adam B. Cox, The Temporal Dimension of Voting Rights (July 2006)

301. Adam B. Cox, Designing Redistricting Institutions (July 2006)

302. Cass R. Sunstein, Montreal vs. Kyoto: A Tale of Two Protocols (August 2006)

303. Kenneth W. Dam, Legal Institutions, Legal Origins, and Governance (August 2006)

304. Anup Malani and Eric A. Posner, The Case for For-Profit Charities (September 2006)

305. Douglas Lichtman, Irreparable Benefits (September 2006)

306. M. Todd Henderson, Paying CEOs in Bankruptcy: Executive Compensation when Agency Costs Are Low (September 2006)

307. Michael Abramowicz and M. Todd Henderson, Prediction Markets for Corporate Governance (September 2006)

308. Randal C. Picker, Who Should Regulate Entry into IPTV and Municipal Wireless? (September 2006)

309. Eric A. Posner and Adrian Vermeule, The Credible Executive (September 2006)

310. David Gilo and Ariel Porat, The Unconventional Uses of Transaction Costs (October 2006)

311. Randal C. Picker, Review of Hovenkamp, The Antitrust Enterprise: Principle and Execution (October 2006)

312. Dennis W. Carlton and Randal C. Picker, Antitrust and Regulation (October 2006)

313. Robert Cooter and Ariel Porat, Liability Externalities and Mandatory Choices: Should Doctors Pay Less? (November 2006)

314. Adam B. Cox and Eric A. Posner, The Second-Order Structure of Immigration Law (November 2006)

315. Lior J. Strahilevitz, Wealth without Markets? (November 2006)

316. Ariel Porat, Offsetting Risks (November 2006)

317. Bernard E. Harcourt and Jens Ludwig, Reefer Madness: Broken Windows Policing and Misdemeanor Marijuana Arrests in New York City, 1989-2000 (December 2006)

318. Bernard E. Harcourt, Embracing Chance: Post-Modern Meditations on Punishment (December 2006)

319. Cass R. Sunstein, Second-Order Perfectionism (December 2006)

320. William M. Landes and Richard A. Posner, The Economics of Presidential Pardons and Commutations (January 2007)

321. Cass R. Sunstein, Deliberating Groups versus Prediction Markets (or Hayek’s Challenge to Habermas) (January 2007)

322. Cass R. Sunstein, Completely Theorized Agreements in Constitutional Law (January 2007)

323. Albert H. Choi and Eric A. Posner, A Critique of the Odious Debt Doctrine (January 2007)

324. Wayne Hsiung and Cass R. Sunstein, Climate Change and Animals (January 2007)

325. Cass. R. Sunstein, Cost-Benefit Analysis without Analyzing Costs or Benefits: Reasonable Accommodation, Balancing and Stigmatic Harms (January 2007)

326. Cass R. Sunstein, Willingness to Pay versus Welfare (January 2007)

327. David A. Weisbach, The Irreducible Complexity of Firm-Level Income Taxes: Theory and Doctrine in the Corporate Tax (January 2007)

328. Randal C. Picker, Of Pirates and Puffy Shirts: A Comments on "The Piracy Paradox: Innovation and Intellectual Property in Fashion Design” (January 2007)

329. Eric A. Posner, Climate Change and International Human Rights Litigation: A Critical Appraisal (January 2007)

330. Randal C. Picker, Pulling a Rabbi Out of His Hat: The Bankruptcy Magic of Dick Posner (February 2007)

331. Bernard E. Harcourt, Judge Richard Posner on Civil Liberties: Pragmatic (Libertarian) Authoritarian (February 2007) 
332. Cass R. Sunstein, If People Would Be Outraged by Their Rulings, Should Judges Care? (February 2007)

333. Eugene Kontorovich, What Standing Is Good For (March 2007)

334. Eugene Kontorovich, Inefficient Customs in International Law (March 2007)

335. Bernard E. Harcourt, From the Asylum to the Prison: Rethinking the Incarceration Revolution. Part II: State Level Analysis (March 2007)

336. Cass R. Sunstein, Due Process Traditionalism (March 2007)

337. Adam B. Cox and Thomas J. Miles, Judging the Voting Rights Act (March 2007)

338. M. Todd Henderson, Deconstructing Duff \& Phelps (March 2007)

339. Douglas G. Baird and Robert K. Rasmussen, The Prime Directive (April 2007)

340. $\quad$ Cass R. Sunstein, Illusory Losses (May 2007)

341. Anup Malani, Valuing Laws as Local Amenities (June 2007)

342. David A. Weisbach, What Does Happiness Research Tell Us about Taxation? (June 2007)

343. David S. Abrams and Chris Rohlfs, Optimal Bail and the Value of Freedom: Evidence from the Philadelphia Bail Experiment (June 2007)

344. Christopher R. Berry and Jacob E. Gersen, The Fiscal Consequences of Electoral Institutions (June 2007)

345. Matthew Adler and Eric A. Posners, Happiness Research and Cost-Benefit Analysis (July 2007)

346. Daniel Kahneman and Cass R. Sunstein, Indignation: Psychology, Politics, Law (July 2007)

347. Jacob E. Gersen and Eric A. Posner, Timing Rules and Legal Institutions (July 2007)

348. $\quad$ Eric A. Posner and Adrian Vermeule, Constitutional Showdowns (July 2007)

349. Lior Jacob Strahilevitz, Privacy versus Antidiscrimination (July 2007)

350. Bernard E. Harcourt, A Reader's Companion to Against Prediction: A Reply to Ariela Gross, Yoram Margalioth, and Yoav Sapir on Economic Modeling, Selective Incapacitation, Governmentality, and Race (July 2007)

351. Lior Jacob Strahilevitz, “Don’t Try This at Home”: Posner as Political Economist (July 2007)

352. Cass R. Sunstein, The Complex Climate Change Incentives of China and the United States (August 2007)

353. David S. Abrams and Marianne Bertrand, Do Judges Vary in Their Treatment of Race? (August 2007)

354. Eric A. Posner and Cass R. Sunstein, Climate Change Justice (August 2007)

355. David A. Weisbach, A Welfarist Approach to Disabilities (August 2007)

356. David S. Abrams, More Time, Less Crime? Estimating the Deterrent Effect of Incarceration using Sentencing Enhancements (August 2007)

357. Stephen J. Choi, G. Mitu Gulati and Eric A. Posner, Professionals or Politicians: The Uncertain Empirical Case for an Elected Rather than Appointed Judiciary (August 2007)

358. Joseph Bankman and David A. Weisbach, Consumption Taxation Is Still Superior to Income Taxation (September 2007)

359. Douglas G. Baird and M. Todd Henderson, Other People’s Money (September 2007)

360. William Meadow and Cass R. Sunstein, Causation in Tort: General Populations vs. Individual Cases (September 2007)

361. removed by author

362. Richard McAdams, Reforming Entrapment Doctrine in United States v. Hollingsworth (September 2007)

363. M. Todd Henderson, From Seriatim to Consensus and Back Again: A Theory of Dissent (October 2007)

364. Timur Kuran and Cass R. Sunstein, Availability Cascades and Risk Regulation (October 2007)

365. David A. Weisbach, The Taxation of Carried Interests in Private Equity (October 2007)

366. Lee Anne Fennell, Homeownership 2.0 (October 2007)

367. Jonathan R. Nash and Rafael I. Pardo, An Empirical Investigation into Appellate Structure and the Perceived Quality of Appellate Review (October 2007)

368. Thomas J. Miles and Cass R. Sunstein, The Real World of Arbitrariness Review (November 2007)

369. Anup Malani, Maciej F. Boni, Abraham Wickelgren, and Ramanan Laxminarayan, Controlling Avian Influenza in Chickens (November 2007)

370. Richard H. McAdams, The Economic Costs of Inequality (November 2007) 
371. Lior Jacob Strahilevitz, Reputation Nation: Law in an Era of Ubiquitous Personal Information (November 2007)

372. Thomas J. Miles and Cass R. Sunstein, The New Legal Realism (December 2007)

373. M. Todd Henderson, Everything Old Is New Again: Lessons from Dodge V. Ford Motor Company (December 2007)

374. Jonathan Remy Nash, Economic Efficiency versus Public Choice: The Case of Property Rights in Road Traffic (December 2007)

375. Edward L. Glaeser and Cass R. Sunstein, Extremism and Social Learning (December 2007)

376. Stephen J. Choi, G. Mitu Gulati, and Eric A. Posner, Are Judges Overpaid?: A Skeptical Response to the Judicial Salary Debate (December 2007)

377. Eric A. Posner, Does Political Bias in the Judiciary Matter?: Implications of Judicial Bias Studies for Legal and Constitutional Reform (January 2008)

378. Susan Bandes, The Heart Has Its Reasons: Examining the Strange Persistence of the American Death Penalty (January 2008)

379. $\quad$ Susan Bandes, After Innocence: Framing Wrongful Convictions (January 2008)

380. Jacob E. Gersen and Ann Joseph O’Connell, Deadlines in Administrative Law (January 2008)

381. Richard A. Epstein, The Property Rights Movement and Intellectual Property (January 2008)

382. Richard A. Epstein, Some Reflections on Custom in the IP Universe (January 2008)

383. Richard A. Epstein, Decentralized Responses to Good Fortune and Bad Luck (January 2008)

384. Richard A. Epstein, How to Create — or Destroy—Wealth in Real Property (January 2008)

385. Richard A. Epstein, The Human and Economic Dimensions of Altruism: The Case of Organ Transplantation (January 2008)

386. Cass R. Sunstein, Adolescent Risk-Taking and Social Meaning: A Commentary (January 2008)

387. Cass R. Sunstein and Adrian Vermeule, Conspiracy Theories (January 2008)

388. Ariel Porat, Expanding Restitution: Liability for Unrequested Benefits (January 2008)

389. Randal C. Picker, Twombly, Leegin and the Reshaping of Antitrust (February 2008)

390. Alon Harrel and Ariel Porat, Aggregating Probabilities across Offences in Criminal Law (March 2008)

391. John Bronsteen, Christopher Buccafusco, and Jonathan Masur, Hedonic Adaptation and the Settlement of Civil Lawsuits (March 2008)

392. Randal C. Picker, Fair Use v. Fair Access (March 2008)

393. Jonathan S. Masur, Process as Purpose: Administrative Procedure, Costly Screens and Examination at the Patent Office (March 2008)

394. Eric A. Posner, Human Welfare, Not Human Rights (March 2008)

395. Lee Anne Fennell, Slices and Lumps, 2008 Coase Lecture (March 2008)

396. Eric A. Posner, Fault in Contract Law (March 2008)

397. Cass R. Sunstein, Is OSHA Unconstitutional? (March 2008)

398. Randal C. Picker, Take Two: Stare Decisis in Antitrust/The Per Se Rule against Horizontal PriceFixing (March 2008)

399. M. Todd Henderson and Anup Malani, Corporate Philanthropy and the Market for Altruism (April 2008)

400. Shyam Balganesh,Foreseeability and Copyright Incentives (April 2008)

401. Cass R. Sunstein and Reid Hastie, Four Failures of Deliberating Groups (April 2008)

402. M. Todd Henderson, Justin Wolfers and Eric Zitzewitz, Predicting Crime (April 2008)

403. Richard A. Epstein, Bell Atlantic v. Twombly: How Motions to Dismiss Become (Disguised) Summeary Judgments (April 2008)

404. William M. Landes and Richard A. Posner, Rational Judicial Behavior: A Statistical Study (April 2008)

405. Stephen J. Choi, Mitu Gulati, and Eric A. Posner, Which States Have the Best (and Worst) High Courts? (May 2008)

406. Richard H. McAdams and Janice Nadler, Coordinating in the Shadow of the Law: Two Contextualized Tests of the Focal Point Theory of Legal Compliance (May 2008)

407. Cass R. Sunstein, Two Conceptions of Irreversible Environmental Harm (Mary 2008)

408. Richard A. Epstein, Public Use ina Post-Kelo World (June 2008)

409. Jonathan R. Nash, The Uneasy Case for Transjurisdictional Adjudication (June 2008)

410. Adam B. Cox and Thomas J. Miles, Documenting Discrimination? (June 2008) 
411. M. Todd Henderson, Alan D. Jagolinzer, and Karl A. Muller, III, Scienter Disclosure (June 2008)

412. Cass R. Sunstein, Trimming (June 2008)

413. Thomas J. Miles and Cass R. Sunstein, Depoliticizing Administrative Law (June 2008) 